\title{
Ageing Population of Urban India \& Psychological Well-being Issues
}

\author{
Pooja Jaggi ${ }^{1 *}$ and Zainab Saleem ${ }^{2}$ \\ ${ }^{1}$ Assistant Professor, Department of Psychology,Mata Sundri College - University of Delhi \\ ${ }^{2}$ Mata Sundri College, University of Delhi, New Delhi, India
}

*Corresponding author: poojajaggi@ms.du.ac.in

Received: 22-04-2020

Revised: $27-07-2020$

Accepted: 20-09-2020

\begin{abstract}
Groundswell in the population of the elderly has multitudinous implications on the economy of a nation as well as the structure of public policies and programmes. Maintaining the health and wellbeing of the elderly, who constitute a large part of India's population is an emerging area of concern in law as well as psychology. This chapter addresses the predicament of the ageing population and the various inequalities and transgressions such as elderly abuse and fiduciary crime that thwart successful ageing and wellbeing. Contemporary conceptions of wellbeing such as that of remarriage, bereavement and resilience in the elderly are also discussed. Furthermore, inadequacies of the policies and programmes developed on the national as well as global level to safeguard the needs of the elderly are also explored.
\end{abstract}

Keywords: Ageing, Health, Wellbeing, Crime against elderly, Governmental Policies

\section{Health, Well-being \& Ageing: An Overview}

\section{Health}

The World Health Organization (1948) adopted a comprehensive and widely accepted view of health, defining it as "a state of complete physical, mental and social well-being and not merely the absence of disease or infirmity."

The traditional biomedical model holds that illness can be fully accounted for by biological variables only, and even the most complex illness phenomenon can be reduced to certain measurable physiological abnormalities. Although this approach is certainly a cut above the ancient view of health that explained illness as resulting from demonic \& spiritual activity, it greatly undermines the influence of other social and psychological factors on health and illness; failing to adequately define the reality of illness in human experience. It takes a reductionist stand, and a dualistic view for mind-body relations, disregarding the continuum of health (DiMatteo \& Martin, 2007).

In furtherance to the biomedical model, the biopsychosocial model necessitated the inclusion of psychological and social factors alongside biological factors in understanding health and illness. This model takes on a more holistic view of health by incorporating the meaning a person attaches to his/her illness, the individuals' unique response style (often learned

How to cite this article: Jaggi, P. and Saleem, Z. (2020). Ageing Population of Urban India \& Psychological Well-being Issues. Int. J. Soc. Sci., 9(03): 169-184.

Source of Support: None; Conflict of Interest: None (क) क 
through patterns of family and culture), his or her social expectations about illness, person's psychological state, as well as the present social context of the illness (DiMatteo \& Martin, 2007).

Health can be categorized into 3 broad components, namely - physical health, mental health \& social health. Physical health includes physical fitness, hygiene, nutrition, and sleep. Mental health includes dimensions of intrapersonal attitudes, growth, development and self-acclimatization, integration, autonomy, accurate perceptions, and environmental mastery. Jourard \& Landsman (1980) proposed that positive self-concept, capability to show sensitivity \& concern about others and the natural world, openness to original ideas, creativity, pragmatic self-perception, capability to work gainfully, and capability to love others, are components of a positive mental health. There are five components of social health and well-being, namely - social integration, social contribution, social coherence, social actualisation and social acceptance (Keyes, 1998).

\section{Well-being}

Wellbeing is a complex, highly subjective and multidimensional construct, often defined in terms of its elements. Diener \& Suh (1997) believed that subjective wellbeing consists of three interrelated components: life satisfaction, pleasant affect, and unpleasant affect. Affect refers to pleasant and unpleasant moods and emotions, whereas life satisfaction refers to a cognitive sense of satisfaction with life. Martin Seligman, the undeniable leader of the positive psychology movement, outlines the following elements of wellbeing which act as building blocks of a flourishing life: Positive Emotion, Engagement, Relationships, Meaning, and Accomplishment (PERMA) (Seligman, 2013). Furthermore, wellbeing or so to say subjective wellbeing canopies concepts of happiness, satisfaction with life, and health.

Emotional wellbeing involves an individual being insightful and aware of affirmed happiness and satisfaction with life. It encapsulates frequent positive affect, rare negative affect, life satisfaction and happiness (Ryff \& Keyes, 1995). Psychological wellbeing is best characterised by self-acceptance, positive relations with others, autonomy, environmental mastery, purpose in life, and personal growth. The concepts of social wellbeing and social health overlap to a great extent.

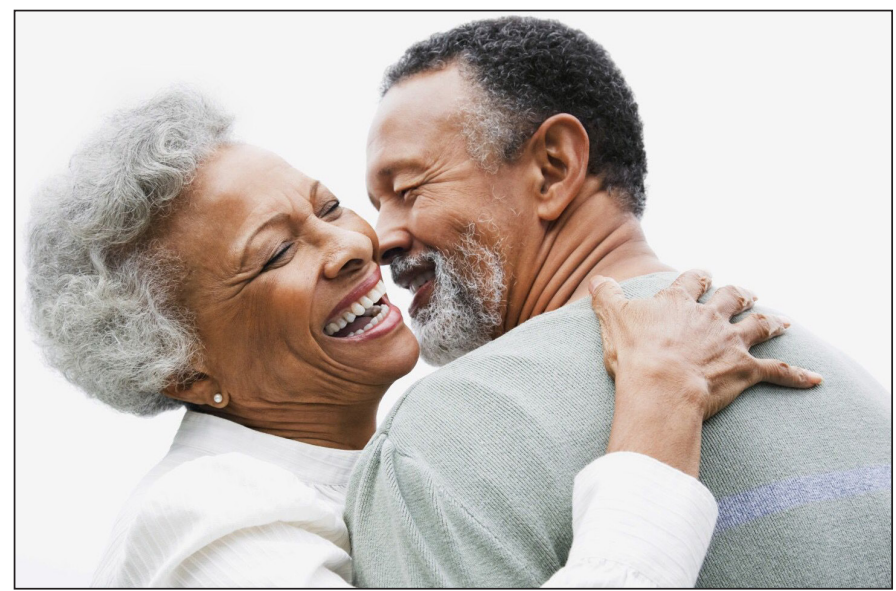

Source: Alyssa Rojas, Pinterest. https://in.pinterest.com/ pin/487444359643882624/?lp=true

Ageing

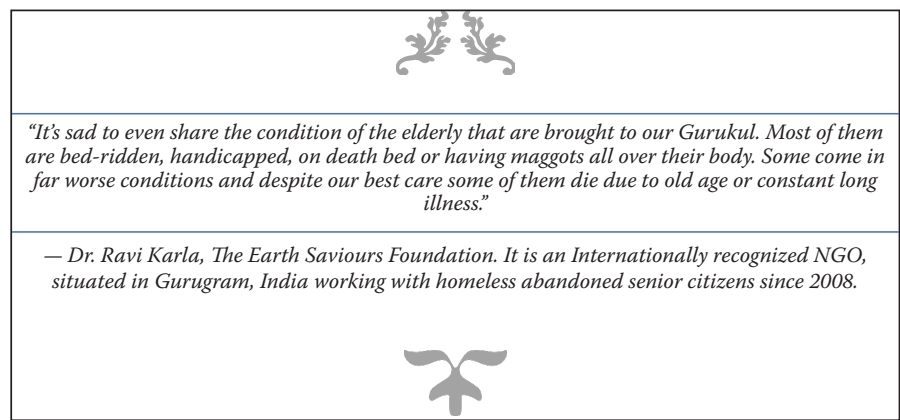

Rise in the elderly population can be attributed partly to advancements in public health and medical technologies, along with improvements in living conditions increasing longevity and lowering mortality rates. The average life span of human beings has increased manifold in the past few decades. However, in this era of globalization and technology, ethics of care and compassion are overpowered by self-interest. The increasingly detrimental social milieu of the elderly has resulted in the need for various legal policies and laws to protect this tenuous population group. This is an unprecedented phenomenon in India, which for centuries had emphasized greatly on collectivism, and catering to the needs of its elderly. 
Groundswell in the number and proportion of older persons, as the baby boomers reach their senior years and as longevity increases, is a worldwide phenomenon often metaphorically termed as 'The Silver Tsunami'. Population ageing has implications for nearly all sectors of society ranging from labour and financial markets, demand for housing, transportation and social protection to family structures and intergenerational ties.

\begin{tabular}{l} 
"The aged suffer silently as materialism steals their traditional \\
seat of honour." \\
\hline - M.P. Mohanty, 1997. New Delhi \\
\hline
\end{tabular}

Ageing is a complex developmental process that is, as yet, poorly understood.

Jeffrey S. Akman (2009) defined ageing in the terms of chronological age and functional age. Chronological age (how old a person is) is commonly used to define an age band of older adults. The start of the period of later life is not fixed and in many Western societies 60-65 years is looked upon as the threshold of old age. The reason for this is possibly related to societal norms (e.g. retirement age) and to the age at which degenerative changes of ageing become noticeable. A person's functional age depends on their performance in relation to age-graded norms. Thus, a person might have a chronological age of 70 but have a functional age of 50 for reaction time and of 60 for speed of information processing. The related term of biological age may be used to relate individual function to age-based norms of physiological functions and, similarly, social age may be used to refer to societal norms of how people should behave at particular ages.

From a physical perspective, ageing involves a loss of resilience or reserved capacity to respond to stressors, and this acquired vulnerability usually means that ageing is associated with some greater susceptibility to illness as well as some decline in function over time.

Normal ageing refers to growing old with a manifest illness, whether physical or mental. This is not entirely uncommon for someone in their 70s. Pathological or sick ageing refers to a process of ageing where there is clear evidence for physical or mental pathology (Baltes, 1991). Finally, optimal ageing implies ageing under the best personal and environmental conditions and is a primary research motivation for many gerontologists.

The current retirement age for most government workers in India is 60 . However, due to ageing population and increasing pressure on pension funding, many countries have begun raising the pensionable retirement age.

The condition of successful ageing if conducive to the experience of optimal health and wellbeing; moreover, they all are interwoven in terms of physical, psychological, social, cultural and spiritual aspects.

\section{(A) Theories of Ageing}

\section{Biological Theories}

The biological theories of ageing can be subsumed under two broad categories - Programmed theory \& Error Accumulation Theory. The programmed theories imply that ageing follows a biological timetable, perhaps a continuation of the one that regulates childhood growth and development. This regulation would depend on changes in gene expression that affect the systems responsible for maintenance, repair and defence responses. This segment constitutes of the theory of programmed longevity (ageing results from sequential switching on and off of certain genes), endocrine theory (ageing is controlled by hormones that act as biological clocks), Immunological Theory (immune functioning deteriorates as body ages leading to increased vulnerability to infectious disease and thus ageing and death). The damage or error theories explains ageing as the result of environmental assaults to living organisms that induce cumulative damage at various levels. Error accumulation theory includes wear and tear theory (ageing is a consequence of wearing out of vital parts of cells and tissues due to repeated use), rate of living theory (the greater an organism's rate of oxygen based metabolism, the shorter its life span), crosslinking theory (ageing results from an accumulation of cross-linked proteins that damage cells \& tissues and thus slow down bodily processes), free radicals theory 
(superoxide and other free radicals cause damage to the macromolecular components of the cell, giving rise to accumulated damage; as a result cells, and eventually organs stop functioning), somatic DNA damage theory (ageing results from damage to the genetic integrity of the body's cells) (Jin, 2010).

\section{Psychosocial Theories}

The activity theory of ageing provides that there is a positive relationship between a person's level of activity and life satisfaction, which further reinforces a positive self-concept and improves adjustment in later life (Havighurst, 1961). Further study of the activity theory revealed that it is also important to take into consideration the type and quality of activity. For example, sustained intimate interpersonal and informal activities are projected to be more beneficial as they increase opportunities for reinforcement of person's selfconcept. Additionally, a sense of subjective well-being can result from an individual solely having a perception of being socially integrated, independent of the actual level of social integration. On the contrary, engaging in in activity that is not meaningful to the participant can actually lead to negative consequences.

The activity theory finds its' roots in the symbolic interactionist theory which holds that a person's identity or self-concept is defined in part by interactions with others and in part by the environment. These interactions impact not only one's behaviour and thought patterns, but also the ageing process. The ageing person may experience loss of personal identity \& wellbeing, low self-esteem, shame or isolation when social withdrawal or role loss occurs by retirement, widowhood or loss of ability to participate in past activities. To age successfully one must continue to be active throughout middle age and beyond, and actively take on productive roles in society, like volunteering, membership in organisations \& social groups; to replace past roles lost as a consequence of ageing.

A major fallback of the activity theory is that it does not take into consideration the influence of other factors such as personality traits, socioeconomic status, and lifestyle characteristics, whilst mapping the relationship between activity and life satisfaction. Public health professionals are one of the major proponents of activity theory, considering their role in prescribing healthpromoting activities specifically targeted to improve health and can have a significant impact on wellbeing beyond that of life satisfaction.

James Dowd's (1975) exchange theory of ageing addresses a perceived loss of status and power associated with ageing. In actuality it is derived from a larger theoretical base known as social exchange theory. The social exchange theory propagates that the social status of a person is determined by the ratio of rewards to costs associated with interaction with that person. Rewards can be actual or perceived, often taking the form of currency, information, goods, services, respect, power, social support, social acceptance, social approval, etc. This theory is based on the assumption that a person's behaviour is in part determined by the person's desire for personal benefit or reward; activities or interactions that are positively reinforced will continue while activities that do not yield sufficient benefit or rewards will be discontinued. Dowd's theory vis a vis ageing, proposes that ageing individuals in industrialized nations lose power and social status as a result of decreasing value of exchangeable good and services. According to Dowd, as ageing people gradually lose control over finances, knowledge, and other resources owing to factors such as retirement, technological developments, and changes in health status, their ability to remain socially and financially viable is inhibited. As a result, their bargaining power is diminished, compelling them to comply with the wishes of others to offer in the exchange. The exchange relationship between younger persons and elderly decreases, making interactions and exchange more costly for younger persons, following the decline in resources of exchange available to the elderly. However, this theory does not address the impact of the context in which the exchange occurs, or how the value or reward may change over time or in a given situation.

\section{Personality \& Ageing-Erikson}

Erik. H. Erikson (1968) propounded the psychosocial theory of development wherein each stage is tied to specific, basic social institutions, is associated with a particular strength, and awakens a specific 
sense of estrangement which can become the basis of psychopathology. Stages of a person's life from birth to death are formed by the interaction of social influences with a physically and psychologically maturing organism. Initial stages counter infancy, early childhood, play age, school age, adolescence and young adulthood. Stages more pertinent to ageing include - adulthood, old age and very old age (Erikson, 1968).

Adulthood is characterised by - the dichotomy between generativity and stagnation, concern with what is generated such as progeny, products, ideas etc., and the establishment of guidelines for the upcoming generations. The primary social institution of adulthood is the family household, with divided labour \& shared household duties. The virtue of care develops, and is expressed by wanting to take care of those needing it, and to share one's knowledge and experience with them; this is accomplished through childrearing, teaching, demonstrating and supervising. When the potential enrichment to be found in generativity fails, the consequences are often seen in the estrangements of the next generation.

The old age stage of the epigenetic process of development is labelled as 'Integrity vs. Despair'. Integrity can be described as a state wherein individuals come to perceive that their life has some order and meaning withing a larger order, apropos their successes and failures of existence, accomplishments, ideas and so on. The individual preserves a personal style of life and defends it from potential threats. The counterpart of integrity is a feeling despair vis a vis vicissitudes of individual life cycle, social and historical conditions, and the nakedness of existence in the face of death. The virtue of wisdom develops out of the encounter of integrity and despair, allowing one to maintain and convey the integrity of one's lifetime of experiences, despite the gradual physical decline of the body. Wise individuals can represent to younger generations a style of life characterized by a feeling of wholeness \& completeness, alleviating feelings of helplessness \& dependence that often mark the end of life.

The very old age is characterised by a chasm between despair and gerotranscendence (Erikson \& Erikson,
1997). Individuals who make it to 90 and beyond typically experience the loss of friends, family and even children. The despair faced by them revolves around their present reality, and not reminiscing about one's life. At such an age, most individuals lose trust in their capabilities; subsequently their purpose in life and autonomy are dulled. Likewise, their identity may become unclear once again, leading them to become isolated and selfabsorbed. However, some very old people hold a special place in their families and/or communities, and may withdraw only by choice, in order to contemplate and be at peace with their life; or in other words, have a last dance with life.

\section{Health \& Well-being of the Aged: Aligning the Inequalities}

Healthy ageing is a broad concept that envelops important aspects of health other than simply the absence of disease; including intellectual, emotional, social, vocational, and spiritual health. Disequilibrium in these areas may impair optimal ageing. Programs designed to facilitate optimal ageing often address arenas of behaviour and lifestyle through education, behaviour modification, and supportive environments. Stats indicate that close to $70 \%$ of physical decline during ageing is related to modifiable and controllable factors such as smoking, poor nutrition, lack of physical activity, injuries from falls etc. In the domain of mental health, it is essential to provide primary health care physicians with the appropriate screening tools, and training and education in geriatrics, to help them better address the health needs of older patients and formulate proper diagnosis and treatment of mental disorders. Finally, access to appropriate and quality health care is critical for healthy ageing. However, as mentioned above most health care professionals lack necessary training in geriatrics to adequately respond to the unique and complex health needs of older adults; which often results in inaccurate diagnoses and inappropriate care. Research shows that older patients receiving care from geriatric-trained professionals show better recovery than those treated with usual care (Lowder, Buzney, French \& Loue, 2008). 
Although until recently it was believed that health promotion efforts are wasted in old age, older adults have recently become an important focus of health promotion efforts. As a result, policy makers now recognize that a healthy older adult population is essential not only for quality of life but also for controlling health care spending (Glass, de Leon, Marottoli \& Berkman, 1999). According to The Merck Institute on Ageing and Health (2004), proper geriatric care could reduce hospital, nursing home, and home care costs by at least $10 \%$ a year, saving $\$ 133.7$ billion in 2020 . An ageing population tends to have a higher prevalence of chronic diseases, physical disabilities, mental illnesses and other comorbidities.

Health promotion efforts with the elderly centre around inter alia, maintaining a balanced diet and regular exercise regimen, taking steps to reduce accidents, reducing indulgence in alcohol \& smoking, reducing the inappropriate use of prescription drugs, obtaining vaccinations against influenza, and remaining socially engaged. Exercise keeps older adults mobile and able to care for themselves. Participating in social activities, running errands, and engaging in light housework or gardening provide social support and a general sense of self efficacy, thereby reducing the risk of mortality (Glass, deLeon, Marottoli, \& Berkman, 1999).

The health needs and health related problems of elderly people cannot be viewed in isolation. A plethora of factors viz social and psycho-emotional concerns (as children move out in search of occupation, the elderly are often left without any physical support in daily activities, feel isolated and experience difficulty in passing the time) (Song et al. 2013), maltreatment towards elderly, poor knowledge about risk factors and nutritional requirements, financial constraints (reduction in income upon retirement may interferes with basic needs), health-care system factors (ineffective health insurance system coupled with accessibility concerns and inadequacies in the government healthcare system) and physical correlates; determine the medical problems and thus cast a significant impact on the quality of life of the elderly. An integrative biopsychosocial approach to health care proves effective in dealing with multiple issues and health habits that need modification.
The aged have become increasingly prone to a gamut of abuse and maltreatment in family as well as institutional settings. This encompasses physical abuse (infliction of pain or injury), psychological or emotional abuse (infliction of mental anguish and illegal exploitation), as well as sexual abuse. A study conducted on 400 community-dwelling older adults beyond the age of 65 years, in Chennai investigated the extent and correlation of elder mistreatment in the specified sample. The results revealed a grotesque $14 \%$ prevalence rate of mistreatment. The results also disclosed that chronic verbal abuse was the most prevailing, shortly followed by financial abuse, physical abuse, and neglect. Moreover, a significantly higher number of women reported facing abuse at the hands of adult children, daughters-in-law, spouses, and sons-in-law; compared to their male counterparts (Chokkanathan \& Lee, 2005).

In India, the elderly people suffer from both communicable as well as non-communicable diseases, further aggravated by impairment of sensory functioning of vision and hearing. The burden of communicable diseases balloons as immunity declines and agerelated physiologic changes occur. The prevalence of tuberculosis is higher among the elderly than younger individuals. More than $50 \%$ of the I individuals beyond 70 years of age suffer more at least one chronic condition ranging from hypertension, coronary heart disease, and cancer. According to Government of India statistics, one third of elderly mortality is accounted for by cardiovascular disorders (Guha, 1994).

A study conducted in rural Pondicherry reported that decreased visual acuity due to cataract and refractive errors was the most common ailment $(57 \%)$ of the elderly followed by pain in the joints and joint stiffness $(43.4 \%)$, dental and chewing complaints $(42 \%)$, and hearing impairment (15.4\%). Other morbidities included hypertension, diarrhoea, chronic cough, skin diseases, heart disease, diabetes, asthma and urinary complaints (A.J. Purty, J. Bazroy, M. Kar, K. Vasudevan, P. Zacharia, \& P. Panda, 2006). Another study conducted among 200 elderly people in Chandigarh observed that as many as $87.5 \%$ had minimal to severe disabilities. Additionally, anaemia was the most prevalent morbidity, followed by dental problems, hypertension, chronic obstructive 
airway disease (COAD), cataract, and osteoarthritis (K. Joshi, R. Kumar \& A. Avasthi, 2003). A community-based study conducted in Delhi among 10,000 elderly people, revealed that problems related to vision and hearing were the most common, closely followed by back ache and arthritis (A. B. Dey, S. Soneja, K. M. Nagarkar, \& H. P. Jhingan, 2001).

Elderly people are highly prone to mental morbidities due to ageing of the brain, cerebral pathology, health issues; as well as socio-economic factors such as breakdown of the family support systems, and decrease in economic independence. The mental disorders that are frequently encountered include dementia and mood disorders. Other disorders include neurotic and personality disorders, drug and alcohol abuse, delirium, and mental psychosis. The rapid urbanization and societal modernization has brought in its wake a breakdown in family values and the framework of family support, economic insecurity, social isolation, and elderly abuse leading to a host of psychological illnesses. Moreover, widows are prone to face social stigma and ostracism.

The most prevalent psychiatric illnesses in the Indian elderly population are depression, dementia and anxiety disorders. Apropos to geriatric mental health issues, it is imperative to increase awareness and capacity building; strengthen training and research activities, develop community-based rehabilitation programmes and develop a holistic primary health care system (Prakash \& Kukreti, 2012).

Dementia is a blanket term for several symptoms related to decline in cognitive functioning. Symptoms are characterized by gradual loss of memory, disorientation, problems with reasoning and judgement, loss of language skills, inability to perform routine tasks and difficulty in learning. Patients of dementia exhibit personality and behavioural deficits as well, such as agitation, anxiety, delusions, and hallucinations. Vascular dementia is a disorder caused by the disruption of blood flow to the brain, the antecedent of which may be the experience of strokes. Depression, drug interactions, and thyroid problems can also cause dementia (Lowder, Buzney, French, \& Loue, 2008).
Alzheimer's is a complex disease of the brain that causes gradual loss of brain cell. Typically, a person with Alzheimer's lives an average of 8 years from the onset of symptoms. More than $70 \%$ of people with Alzheimer's disease live at home and almost $75 \%$ of the home care is provided by family and friends, creating a great need for caregiver support and training (Lowder, 2008).

Parkinson's disease is a common chronic degenerative disorder of the central nervous system that affects mobility and locomotion. Symptoms like tremors, muscle rigidity, rhythmic muscle contractions, sleep disturbances, confusion, slow bodily movement and speech impairments result from progressive damage of neuron endings present in the basal ganglia. Approximately $0.3 \%$ of the world population and $1 \%$ of the elderly population suffer from Parkinson's disease. There are very few large multicentre population-based studies determining the exact incidence and prevalence of Parkinson's in India (de Lau \& Breteler, 2006).

\section{Health \& Well-being: Emerging Perspectives}

\section{Successful Ageing}

Professor Margaret Baltes and her colleagues at the Free University of Berlin in Germany developed the model of selection, optimization and compensation to illustrate the phenomenon of successful ageing (Baltes \& Carstensen, 2003). In this model it is proposed that those who age successfully make concentrated endeavours in selected life areas that are significant to them, optimally use the resources that facilitate success in the preferred areas, and make up for losses required for success in these areas in order to accommodate to increasing biological, psychological, and socioeconomic constraints associated with ageing. Well-adjusted older adults carefully choose a limited number of valuable goals that provide them a purpose in life. They then use techniques and aids to help them overcome obstacles such as physical decline and illness, psychological limitations such as memory issues, and socio-economic constraints such as declining finances to allow them to achieve those valued goals. For example, in a 7-year longitudinal study of over 900 older adults living in Chicago, Boyle et al. (2010) found that those with a high 
score on a purpose in life inventory were at lower risk of developing Alzheimer's disease and mild cognitive impairment and therefore had a better quality of life (Boyle, Buchman, Barnes, \& Bennett, 2010).

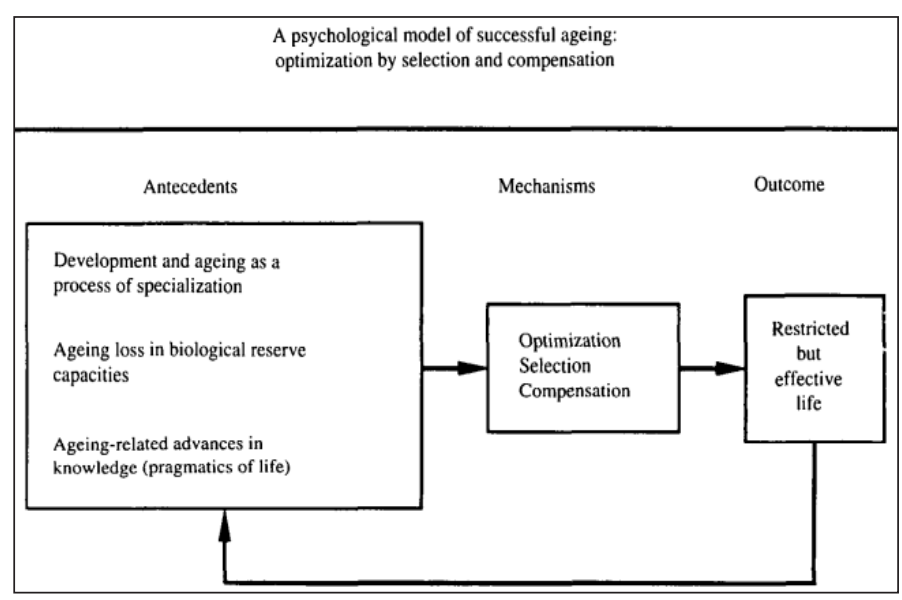

Fig. 1. Model of successful ageing (Reproduced from Baltes P. B., 1991)

\section{Grandparental Roles}

Thiele \& Whelan (2006) concluded in their wide-ranging analysis that the role of grand parent is usually important and fulfilling, likely because it offers an outlet for individuals to fulfil their generativity needs. Neugarten and Weinstein (1964) identified 5 types of grandparental roles. Firstly, there were those who took on a formal role and were engaged with the grandchildren not in childcare but lovingly and emotionally. The second role was simply fun-seeking, and for the grandchildren these grandparents served as playmates. The third type of role is that of a distant figure who had little interaction with grandchildren was the third type of grandparental position. The fourth role-type was that of parental surrogate, and these grandparents assume the role of parent to the grandchildren in order to allow the mother to work outside the home. The ultimate grandparental function was that of a family knowledge repository that occupied within the extended family a powerful patriarchal or matriarchal position. Where grandparents follow principles, which are supportive to the parents and grandchildren, they contribute to resilience in the family. Wherever they take on positions that greatly increase demands on parents and grandchildren without offering support, they indirectly contribute to the development of maladjustment (Neugarten \& Weinstein, 1964).

\section{Bereavement}

The death of a loved one is one of the most stressful and emotionally devastating event a person can experience. Bereavement is the fact of loss through death, and is usually accompanied by overwhelming grief and mourning. Bereavement can bring changes in a person's physiological and psychological health and wellbeing, as well as, social status and interpersonal relationships; it may also hamper one's agility to cope with circumstances. The death of spouse has especially multitudinous implications in old age. Loneliness, depression, decreased psychological wellbeing, lower levels of social support, decreases in morale, difficulties with new roles and responsibilities, challenges to a sense of personal identity, and physical health problems are all associated with bereavement in elderly men and women (DiMatteo \& Martin, 2007).

\section{Resilience}

Carol Ryff (1989) and colleagues provided six factors that represent resources for effective living and resilience. The first being self acceptance which is expressed through having a positive attitude towards oneself, acceptance of strengths and weaknesses, and positive feelings about life. Personal growth is indicative of a person's feeling of continued development and effectiveness, along with an openness to new experiences. To ensure wellbeing a person must also have a meaningful purpose in life which is characterised by personal goals and beliefs, that direct one's life. Environmental mastery refers to a feeling of competence which is reflected in one's ability to create a personally suitable living situation, and condition necessary for a successful life. Autonomy is a critical element of wellbeing and resilience; autonomous people are self-directed, work independently and resist negative social pressures. Lastly, having positive relations that are warm, satisfying and supportive, as well as being capable of empathy and intimacy are crucial in ensuring wellbeing and resilience in old age. 


\section{Remarriage}

Remarriage among the elderly is an increasingly prevalent phenomenon. The prospect of remarriage is different for elderly than it is for young or middleaged persons as they have distinctive needs and circumstances. Older person may appear selfish, disrespectful, and untrue to their previous spouse and family due the stereotypes and taboos attached to old age. Moreover, children tend to perceive parents only in the limited role of a parent who is self-sacrificing \& asexual; hence, it is difficult for them to comprehend the fact that they have sexual and companionship needs and may get very lonely without a partner. This difficulty in accepting a new family member is coupled with the strong tradition of filial responsibility that leads them to perceive remarrying parents as an evidence of the children's failure in providing for their parents; they may resist the marriage out of their own guilt (Katschke-Jennings \& Healey, 1988). However, while remarriage can redress loneliness, it can cause potential legal complications for adult children in property distribution and rights. Worries about what society will think and even what their adult children's in-laws will think, coupled with the children's fears of loss of inheritance or assets sometimes leads to strong family disapproval. Further legal implications related to pension and health care makes elderly remarriage a convoluted pursuit; augmenting the older person's crippling loneliness and well-being. Fortunately, in recent years, children are becoming increasingly open to the idea, and even actively coming forward to find partners for their parents. In some cases, the children live in another city or work full-time and are not able to care for their parent, and would like them to find a partner.

\section{Urban Profile: Mapping the Patterns}

\section{Global}

Globally, the population aged 65 and over is growing faster than all other age groups. The World Population Prospects: The 2019 Revision, revealed that by 2050, the global population of older persons is projected to more than double its size in 2015, reaching nearly 2.1 billion and one in six people in the world will be over age 65 (16\%), up from one in 11 in 2019 (9\%). By 2050, one in four persons living in Europe and Northern America could be aged 65 or over. Globally, for the first time in history in 2018, children under five years of age were outnumbered by persons aged 65 years or above. The number of persons aged 80 years or over is projected to triple, from 143 million in 2019 to 426 million in 2050. The global population of older persons is projected to more than double its size in 2015 by 2050, reaching nearly 2.1 billion. Between 2000 and 2015, population of persons aged 60 years or over increased by $68 \%$ in urban areas, compared to a $25 \%$ increase in rural areas, at a global level. In the years 2010-2015 women accounted for 54 per cent of the global population aged 60 years or over. As a result, the share of older persons in the total population is increasing virtually everywhere. Population ageing, although a global phenomenon, is disproportionate in developed and developing countries. By 2050, 44 per cent of the world's population is estimated to live in relatively aged countries, with at least 20 per cent of the population aged 60 years or over.

\section{India}

$1 / 8^{\text {th }}$ of the Worlds Elderly Population lives in India. According to the State of World Population 2019 report by the United Nations Population Fund (UNFPA), six per cent of India's population was of the age 65 and above. The elderly population of India is projected to increase to about 300 million by 2050 . India has thus acquired the label of "an ageing nation" with $7.7 \%$ of its population being more than 60 years old (Premchand, 2016). The All India Senior Citizen's Confederation (AISCONN) revealed that the life expectancy of those above the age of 70 years has increased by $18 \%$; however, this rise does not necessarily reflect improved quality of life. Reports of the Ministry of Statistics indicate that the old age dependency ration - measure of the pressure on the economically productive section of the population, hiked from $10.9 \%$ in 1961 to 14.2 \& in 2011. Although $41.6 \%$ of the elderly population still works, very few feel financially secure. Delhi (NCR), the capital of India, has a total population of over 2 crores, of which $8 \%$ are above the age of 60 , that is, over 12 lakh elderly people. 
Old age becomes ever more distressing to the portion of this population that had migrated from other parts of the country, and have trouble assimilating to the changed environment.

The demographic landscape is transitioning as a result of soar in the population of baby boomers coming to age. This spurt in the elderly population poses serious structural threats to the fiscal sustainability and public finance of a nation, in the way that decrease in government's ability to collect tax revenue due to shrink in tax-paying working population is paralleled by increase in governmental expenditures of age related programs, particularly healthcare expenditure, pension. Diminishing productivity is corresponded with a reduction in economic growth which is the foundation of economic and social development, and reduction in national revenues and savings; generating negative impacts on economic sustainability. A country can be at risk of insufficient social development and economic in-sustainability, owing to sluggish economic growth. Yoshino and Miyamoto (2017) evidenced that population ageing weakens the effectiveness of traditional macroeconomic - fiscal and monetary policies. Effectiveness of fiscal policy - which relies heavily on tax collection, is diminished as a result of lower total labour supple in the economy. As retirees' pension benefits are financed by active tax payers, overall burden per worker is substantially raised with a decreasing working population. With regard to monetary policy, a ratio of population directly affected by the monetary policy shock decreases as the consumption behaviour of the aged is not affected by change in interest or inflation rates due to their limited income and fixed spending behaviour. Population ageing has serious economic implications, it is imperative to develop more structured responses and reforms to address such challenges (Yoshino \& Miyamoto, 2017).

\section{Right to Health: Current Predicament \& Public Policy}

Age is one of the key criteria for various protections and benefits that extend to older citizens provided by the society or nation. As discussed earlier, defining the age at which one becomes senescent is one of the foremost challenges in identifying legal issues vis a vis the elderly. Ageing, in essence, is a natural developmental process, but its experience is relative; and so, in many ways defining ageing extends beyond the chronological age and incorporates behaviour, physical status as well as attitudes. Ageing also brings an increased risk of illness, incapacity, and death, although none of these misfortunes are exclusive to older individuals.

Given the current socioeconomic and cultural ethos, a lion's share of the aged population never retires in the usual sense of the term and continue to work for as long as physically possible. As in when the ability to produce and earn inevitably declines with age, most older persons deal with absence of savings, which mirrors decline in living standards and for many, even destitution. This is the challenge of old age income security in India; creating an urgency for all aspects of care including socioeconomic, financial, health and shelter, for the aged.

The plight of elderly women in exacerbated by a lifetime of gender-based discrimination stemming from deep-rooted cultural and social bias; in addition to discrimination on the grounds of class, caste, disability, illiteracy, unemployment, marital status and access to property rights. Aged women also have lesser time to spend on recreational activities and leisure, compared to their male counterparts who are not burdened with household chores for the most part of their life. Physiologically, women endure proportionately higher rates of chronic illness and disability in later life than men. Moreover, social and mental health of elderly women is compromised to a greater extent if they are single or widowed; more than half of women over the age of 80 years are widows. Sociologist Patricia Uberoi (1996) remarked that remarriage of women has not been culturally acceptable perhaps owing to the fact that elderly widows have relatively less assets.

The aged have become increasingly prone to a gamut of abuse and maltreatment in family as well as institutional settings. The encompasses physical abuse (infliction of pain or injury), psychological or emotional abuse (infliction of mental anguish and illegal exploitation), as well as sexual abuse. A study conducted on 400 
community-dwelling older adults beyond the age of 65 years, in Chennai investigated the extent and correlation of elder mistreatment in the specified sample (Chokkanathan \& Lee, 2005). The results revealed a grotesque $14 \%$ prevalence rate of mistreatment. The results also disclosed that chronic verbal abuse was the most prevailing, shortly followed by financial abuse, physical abuse, and neglect. Moreover, a significantly higher number of women reported facing abuse at the hands of adult children, daughters-in-law, spouses, and sons-in-law; compared to their male counterparts.

Elderly abuse is an unspoken horror that stains the lives of many older persons. Victims of abuse and maltreatment are three times more likely to die within a decade. Majority of preparators of elderly abuse are care givers and relatives who are pushed to the brink of violence and neglect by overwhelming responsibility and stress. Abuse may be disguised in the form of passive neglect, when caregivers lack the resources or knowledge to efficiently take care of an older adult. In case the preparators are not caregivers or kin, they seek to exploit the dependency of older adults when they are most vulnerable (Souare \& Lloyd, 2008). AISCCON reports unveiled that the elderly population of India is disproportionately vulnerable to crime, particularly in the arenas of electronic, with bank and credit card frauds. In a similar vein, AISCCON Survey 2015-16 revealed that a myriad of $60 \%$ of older person living with their families are subject to abuse and harassment; of which, $66 \%$ are destitute or BPL and 39\% live alone or have been abandoned. The loneliness and mental health issues that accompany living alone are manifold. India recognises World Elderly Abuse Day on $15^{\text {th }}$ June.

Fiduciary abuse, exploitation and financial mistreatment encompass a broad range of conduct. For instance, attendants short-changing their elderly clients, neighbours who secure power of attorney to help out with chores often exploit it to take possession over the aged person's home, and children who manipulate vulnerable and impaired elderly family member to change the will in their favour (Souare \& Lloyd, 2008). Fiduciary is most difficult to grasp and evaluate, as it often involves complex and subjective determinations, differentiating between misconduct and mismanagement, and between acceptable exchange and exploitative conduct. Abuse may be concealed by the victim's diminished mental capacity, as there remains a certain ambiguity regarding whether the aged person understood the transactions completely, or if they were victims of unfair persuasion. Elderly are often fall prey to fiduciary abuse as they are more trusting than their younger counterparts, they may not realise the value of their assets, they are more likely to have conditions and disabilities that make them vulnerable and docile and they are less likely to take legal action against their preparators, specially if they are kin. Preparators also exploit the fact that those who are in extremely poor health may not survive long enough to follow through lengthy legal interventions.

As highlighted previously, needs of older persons have changed momentously given their volatile socioeconomic milieu, growing popularity of nuclear families and rapidly deteriorating traditional value systems. Older persons ability to act for the betterment of themselves and development of their societies should be woven into policies and programmes at all levels.

\section{Global Policies}

Adopted in 2002, The Madrid Plan of Action (MIPAA) offers a bold new agenda for handling the issue of

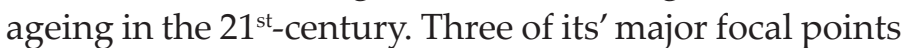
are: older persons and development; advancing health and well-being into old age; and ensuring enabling and supportive environments. It serves as a resource for policymaking, suggesting ways for Governments, nongovernmental organizations, and other actors to reorient the ways in which their societies perceive, interact with and care for their older citizens. The Madrid Plan of Action also represents the first time 159 governments agreed to link questions of ageing to other frameworks for social and economic development and human rights. It also calls for governments to include older people in the development of the policy development process. Furthermore, the MIPAA is not legally binding and its implementation is voluntary.

Broadly, the central themes and objectives of the International Plan of Action on Ageing, 2002 incapsulate inter alia, the recognition of the unique situation 
and circumstances of ageing in indigenous persons, harnessing of scientific research and expertise focusing on the multi-faceted implications of ageing, support and social protection of older persons including preventive and rehabilitative health care, facilitating partnership among various societal and governmental structures and the elderly, commitment to gender equality among older persons, elimination of all forms of violence and discrimination against older persons, achievement of secure ageing and full realization of all human rights and fundamental freedoms of all older persons.

\section{Policies Safeguarding the Elderly in India}

\section{(i) Constitutional Provisions}

Our culture's sensitivity, respect, morals, care and concern apropos our elderly are enshrined in the Constitution of India itself. Article 41 of Directive Principles of State Policy has particular relevance to Old Age Social Security. According to this Article, "the State shall, within the limits of its economic capacity and development, make effective provision for securing the right to work, to education and to public assistance in case of unemployment, OLD AGE, sickness and disablement and in other cases of undeserved want".

Entry 24 in the Concurrent List (List 3) of Schedule VII of the constitution concerns with 'Welfare of labour including conditions of work, provident funds, employers' liability, workmen's compensation, invalidity and old age pensions and maternity benefits.' Additionally, entry 9 of the State List (List II) reflects concern regarding 'relief of the disabled and unemployable.' Similarly, item 20 and 23 of the Concurrent List relate to old age pension, social security and social insurance, and economic and social planning.

\section{(ii) Programmes \& Schemes}

The National Social Assistance Programme (NSAP) was first launched on $15^{\text {th }}$ August, 1995 is a welfare programme being administered by the Ministry of Rural Development as a Centrally Sponsored Scheme; it comprised of the National Old Age Pension Scheme (NOAPS), National Family Benefit Scheme (NFBS) and National Maternity Benefit Scheme (NMBS). It provides financial assistance to the elderly, widows and persons with disabilities in the form of social pensions.

The Indira Gandhi National Old Age Pension Scheme (IGNOAPS), 2007 is a non-contributory old age pension scheme that maintained that all persons of 60 years (and above) and living below the poverty line, are eligible to be a beneficiary of the scheme. Presently, IGNOAPS beneficiaries aged 60-79 years receive a monthly pension amount of INR 400, those of age 80 and above receive INR 500. States are strongly urged to provide an additional amount at least an equivalent amount to the assistance provided by the Central Government so that the beneficiaries can get a decent level of assistance.

The Continuing Education and Adult Education programmes in India. Adult Education programmes aim at extending educational options to those adults, who have lost the opportunity and/or have crossed the age of formal education, who now feel a need for learning of any type, including literacy, basic education, vocational education and equivalency. A series of programmes have been introduced since the First Five Year Plan, keeping in mind the key objective of promoting adult education; the most prominent being the National Literacy Mission (NLM), that was launched in 1988 to impart functional literacy to non-literates in the age group of 15-35 years in a time bound manner.

\section{(iii) Concessions and Facilities given to Senior Citizens by Different Ministries/Departments of the Government of India}

Ministry of Finance: The Ministry of Finance has supervised various senior citizen health insurance plans, wherein high medical costs during hospitalization are met by paying a premium each year to the insurer who pays the sum insured in case of medical treatment. This aims to shoulder the financial burden the elderly face in times of health crisis, and hence to indirectly stress and anxiety revolving around frequent health concerns during old age.

The Ministry of Finance also spares certain tax benefits to senior citizens not having income from profits and gains of business or profession; in the sense that they shall not be liable to pay advance tax and be allowed to 
discharge their tax liability (other than TDS) by payment of self-assessment tax. Moreover, Senior citizens receive a higher interest (up to $50 \mathrm{bps}$ ) on a five-year fixed deposit which is entitled for deduction from income tax. Older persons of 60 years and above are exempted from income tax up to ₹ 3 lakh per annum.

Ministry of Health \& Family Welfare: The Ministry of Health and Family Welfare has conceived the National Programme for the Health Care for the Elderly (NPHCE) 2010-11 which provides preventive, curative and rehabilitative services to the elderly. Its objectives also include providing persons at various level of health care delivery system of the country, developing specialized man power, promoting research in the field of diseases related to old age, and strengthening the referral system. A total of 104 districts of 24 States/UTs and 8 Regional Geriatric Centres have been covered under the Programme.

Ministry of Home Affairs: The Ministry of Home Affairs in its advisories has advised the States/UTs to take immediate measures to ensure safety and security and for elimination of all forms of neglect, abuse and violence against old persons through initiatives such as identification of senior citizens; sensitization of police personnel regarding safety, security of older persons; regular visit of the beat staff; setting up of toll free senior citizens helplines; setting up of senior citizen security cell; verification of domestic helps, drivers, etc.

Chapter V of the Maintenance and Welfare of Parents and Senior Citizens Act, 2007 provides for protection of life and property of senior citizens, and ensures need-based maintenance for parents and senior citizens and their welfare.

Ministry of Personnel, Public Grievances and Pensions: The Department of Pension \& Pensioners' Welfare, Government of India contrived 'Sankalp' an initiative to provide a place for the pensioners to access opportunities available for useful interventions in the society. 'Anubhav' is a platform for retiring employees to showcase significant achievements made during their service period giving the employees an opportunity in creating a useful database of future.

\section{Health \& Wellbeing Dilemmas: The Critical Areas of Research in Law}

The socioeconomic problems of the elderly are aggravated by lack of social security and subpar facilities for health care, recreation and rehabilitation. In most developing countries, pension and social security are enjoyed by those who have worked in the public sector, to the exclusion of others; as a result, a vast number of the aged population especially those from rural areas are left to fend for themselves during such a vulnerable period of their life. Economic policies must be generated to safeguard the socioeconomic security of this silent majority.

Crime statistics have traditionally suggested that people aged 60 or over are less likely to be the victims of violent crime compared to the rest of the population. However, most victimisation surveys exclude certain groups such as those residing in care homes and hospitals. In addition, research usually examines a fairly narrow range of violence and abuse, not accounting for sexual violence and violence that leads to fatality. Skewed statistics can also be accounted for by instances of elderly violence and abuse that are often disregarded by police forces, health professionals and other key agencies because of ageist assumptions about older people being at low risk for violence. This results in missed opportunities to identify and prevent violence against older people. Thus, further research in law, criminology and gerontology must counter in these variables, so as to provide results reflective of the true scenario of the elderly and facilitate further policy making.

The institutional care system for the elderly is still in its nascent phase in India, confined to the developed metropolitans and affordable by those who are well off. Even now, elderly care is predominantly dependent on community care and family care. However, rapid modernisation, breakdown of joint family system, and migration of the young working population to urban areas has further dilapidated elderly care. Health care providers like nurses, assisted living care takers, and old age home employees and volunteers are often under trained and may end up negatively impacting the health and wellbeing of the older persons under their 
care. Moreover, the elderly are most adversely affected by poor infrastructure (roads and housing), inefficient health care system and dearth of human and technical resources vis a vis hospitals and other institutions. The operation of the philosophical fair innings argument often provides grounds that legitimate giving lower priority to policies that primarily benefit the elderly.

Research carried out by Agewell Foundation India on 50,000 older persons regarding legal provisions \& practices evidenced that $14.05 \%$ did not opt for legal justice as they could not afford high fees of lawyers owing to their weak financial condition and dependence. Furthermore, lack of awareness regarding legal laws and provisions made for the welfare and empowerment of older persons is another ingredient of elderly injustice. Only 9990 out of 50,000 older persons admitted that they were aware of some elderly friendly legal provisions available in the country. Further analysis revealed that only $7.06 \%$ of elderly women and $16.7 \%$ elderly men had some knowledge of the Maintenance \& Welfare of Parents \& Senior Citizens Act, 2007.

Additionally, in spite of being aware of the legal provisions many old age parents may hesitate to use these provisions due to social sanction and guilt attached to acting against your own loved ones.

\section{CONCLUSION}

Issues and challenges related to elderly population are going to become even more critical. If this population is well managed and addressed can serve as an important resource which can meaningfully contribute to the economy and knowledge capital of the country. Though the role of law is critical to alleviate the socio-economic problems of the elderly but the societal and familial structures also have equally important role to play. Elderly friendly government policies in health, legal and civil sector will go a long way in providing long term security and optimum well being this expanding and important population group. Elderly need to counselled to use legal provisions if they are facing abuse and exploitation due to ill treatment by family members. The taboo against legal recourse should be reduced by creating awareness, though they should be resorted to as the last option.

\section{REFERENCES}

Adult Education I Government of India, Ministry of Human Resource Development. (2019). Retrieved 11 December 2019, from https://mhrd.gov.in/adult-education

Agewell Research \& Advocacy Centre Comprehensive Study on Status of Older Persons. 2019. Retrieved 10 November 2019, from https:// www.agewellfoundation.org/pdf/Agewell\%20Study\%20Oct2012-website\%20(1).pdf

Akman J. 2009 The developmental psychology of aged persons. In Developmental Psychology: Main Problems and Modern Tendencies (Encyclopedia of Social Sciences and Humanities). UNESCO - Encyclopedia of Life Support Systems. Retrieved from: https://www.eolss.net/ ViewChapter. aspx?CategoryId=4).

An elderly parents' remarriage has implications for the entire family. 2019. Retrieved 23 December 2019, from https://www.etelf. com/elderly-parents-remarriage-implications-entire-family/

Carr, A. 2013. Positive Psychology, Second Edition. Hoboken: Taylor and Francis.

Chokkanathan, S. and Lee, A. 2005. Elder Mistreatment in Urban India: A Community Based Study. Journal of Elder Abuse $\mathcal{E}$ Neglect, 17(2): 45-61.

Baltes, M. and Carstensen, L. 2003. The Process of Successful Aging: Selection, Optimization, and Compensation. Understanding Human Development, pp. 81-104.

Baltes, P. 1991. The many faces of human ageing: toward a psychological culture of old age. Psychological Medicine, 21(4): 837-854.

Boyle, P., Buchman, A., Barnes, L. and Bennett, D. 2010. Effect of a Purpose in Life on Risk of Incident Alzheimer Disease and Mild Cognitive Impairment in Community-Dwelling Older Persons. Archives of General Psychiatry, 67(3): 304-310.

Datta. 2019. Eldercare: Demographic downside. Retrieved 18 December 2019, from https://www.indiatoday.in/magazine/ nation/story/20180507-branded-corporate-elderly-care-oldage-homes-1221657-2018-04-26

De Lau, L. and Breteler, M. 2006. Epidemiology of Parkinson's disease. The Lancet Neurology, 5(6): 525-535.

Dey, A.B., Soneja, S., Nagarkar, K.M. and Jhingan, H.P. 2001. Evaluation of the health and functional status of older Indians as a prelude to the development of a health programme. The National Medical Journal of India, 14(3): 135-138.

Diener, E. and Suh, E. 1997. Measuring Quality of Life: Economic, Social and Subjective Indicators. Social Indicators Research, 40(1/2): 189-216.

Dimatteo, M. and Martin, L. 2007. Health psychology. Delhi: Pearson Education.

Dommaraju Premchand. 2016. Perspectives on Old Age in India. doi: 10.1007/978-3-319-24783-0_19. 
Dowd, J. 1975. Aging as Exchange: A Preface to Theory. Journal of Gerontology, 30(5): 584-594.

Erikson, E.H. 1968. Identity: Youth and crisis (No. 7). WW Norton \& Company.

ET Online. 2019. Retirement age set to rise due to higher life expectancy: Economic Survey. Retrieved 31 November 2019, from https://economictimes.indiatimes.com/news/economy/ indicators/retirement-age-set-to-rise-due-to-higher-lifeexpectancy-economic-survey/articleshow/70071852.cms

Guha, R. 1994. Morbidity related epidemiological determinants in Indian aged: An overview. Public health implications of ageing in India. New Delhi: Indian Council of Medical research.

Hamid, Z. 2019. They are 60, 70 or 80 years of age and finding love again. Retrieved 23 December 2019, from https://www. thehindu.com/society/love-again-they-are-60-70-or-80-andfinding-life-partners/article22429443.ece

Havighurst, R. 1961. Successful Aging. The Gerontologist, 1(1): 8-13.

Helpage India. 2019. Retrieved 12 November 2019, from https:// www.helpageindia.org/wp-content/uploads/2017/06/seniorcitizens-guide-2016.pdf

Human Rights of Elderly in India: A Critical Reflection on Social Development. 2019. Retrieved 19 December 2019, from https://www.agewellfoundation.org/pdf/reports/Human $\% 20$ Rights\%20of\%20Elderly\%20in\%20India\%20-\%20A\%20 Critical\%20Reflection\%20on\%20Social\%20Development $\% 20$ -\%20July\%202015.pdf

Ingle, G.K. and Nath, A. 2008. Geriatric health in India: Concerns and solutions. Indian journal of community medicine: official publication of Indian Association of Preventive $\mathcal{E}$ Social Medicine, 33(4): 214.

Jin, K. 2010. Modern Biological Theories of Aging. Aging and Disease, 1(2): 72-74.

Joshi, K., Kumar, R. and Avasthi, A. 2003. Morbidity profile and its relationship with disability and psychological distress among elderly people in Northern India. International Journal of Epidemiology, 32(6): 978-987.

Jourard, S. and Landsman, T. 1980. Healthy personality. New York: Macmillan.

Kartikeyan, S., Pedhambkar, B.S. and Jape, M.R. 1999. Social security the Global Scenario. Indian J Occup Health, 42(2): 91-8.

Katschke-Jennings, B. and Healy, D. 1988. Remarriage and the Elderly. Journal Of Religion \& Aging, 3(3-4): 1-11.

Kelland, M. 2017. Personality Theory. OER Commons. Retrieved December 22, 2019, from https://www.oercommons.org/ authoring/22859-personality-theory.

Keyes, C. 1998. Social Well-Being. Social Psychology Quarterly, 61(2): 121-140.
Khandelwal S.K. 2003. Mental health of older people. In: Dey $\mathrm{AB}$, Ageing in India. Situational analysis and planning for the future. Rakmo Press, New Delhi.

Legal Provisions \& Practices in India with Special Focus on Human Rights of Old People. 2019. Retrieved 14 November 2019, from https://www.agewellfoundation.org/pdf/ Agewell\%20Legal\%20Study\%202012.pdf

Lowder, J., Buzney, S., French, C. and Loue, S. 2008. Legal Aspects of Aging. Encyclopaedia of Aging and Public Health, pp. 35-47. doi: 10.1007/978-0-387-33754-8_459

Madrid Plan of Action. 2019. Retrieved 31 December 2019, from https://www.un.org/en/events/pastevents/pdfs/Madrid_plan. pdf

National Policy on Senior Citizens. 2011. Retrieved from: http:// socialjustice.nic.in/writereaddata/UploadFile/dnpsc.pdf

Neugarten, B. and Weinstein, K. 1964. The Changing American Grandparent. Journal of Marriage and The Family, 26(2): 199-206.

Official Records of the World Health Organization, 2 (1948, p. 100), Geneva.

Parkinson's Disease. (n.d.). Retrieved from https://www.nhp.gov. in/disease/neurological/parkinson-s-disease.

Prakash, O. and Kukreti, P. 2012. State of Geriatric Mental Health in India. Current Translational Geriatrics and Experimental Gerontology Reports, 2(1): 1-6.

Purty, A.J., Bazroy, J., Kar, M., Vasudevan, K., Zacharia, P. and Panda, P. 2006. Morbidity pattern among the elderly population in the rural area of Tamil Nadu, India. Turkish Journal of Medical Sciences, 36(1): 45-50.

Ryff, C. 1989. Happiness is everything, or is it? Explorations on the meaning of psychological well-being. Journal of Personality and Social Psychology, 57(6): 1069-1081.

Ryff, C. and Keyes, C. 1995. The Structure of Psychological Well-being Revisited. Journal of Personality and Social Psychology, 69(4): 719-727.

Seligman, M. 2013. Flourish. New York: Atria.

Shrivastava, S.R., Shrivastava, P.S. and Ramasamy, J. 2013. Healthcare of Elderly: Determinants, Needs and Services. International Journal of Preventive Medicine, 4(10): 1224-1225.

Song, Y., Ma, W., Yi, X., Wang, S., Sun, X. and Tian, J. et al. 2013. Chronic Diseases Knowledge and Related Factors among the Elderly in Jinan, China. Plos ONE, 8(6).

Souare, G. and Lloyd, L. 2008. The History and Demography of Aging in the United States. Encyclopaedia of Aging and Public Health, pp. 11-22. doi: 10.1007/978-0-387-33754-8_457

Thiele, D. and Whelan, T. 2006. The Nature and Dimensions of the Grandparent Role. Marriage \& Family Review, 40(1): 93-108.

UBEROI, P. 1996. The Family in Official Discourse. India International Centre Quarterly, 23(3/4): 134-155. 
United Nations, Department of Economic and Social Affairs, Population Division. 2015. World Population Ageing 2015 (ST/ ESA/SER.A/390).

World Health Organization. Elder maltreatment. 2011. Retrieved from: http://www.who.int/mediacentre/factsheets/fs357/en/)
Yoshino, N. and Miyamoto, H. 2017. Declined Effectiveness of Fiscal and Monetary Policies Faced with Aging Population in Japan, Journal of Japan and the World Economy, pp. 42, Elsevier, Tokyo. 